\title{
Tresguerras, \\ el sueño y la melancolía
}

Para Jorge Cruz Vera

Proemio

$\square$

NTRE UNA SERIE de ocho autorretratos de don Francisco Eduardo Tresguerras destaca uno dibujístico, de sus últimos años juveniles, dada la riqueza de los motivos plásticos y literarios que allí se conjugan. Según confesión de su puño y letra, lo hizo en Q uerétaro una noche lluviosa y calurosa de julio de i796, cuando contaba treinta y siete años de edad. Éste era el momento en que escribía el grueso del primer tomo de sus 0 cios lite rarios y sus controversias, cruzadas con sus rivales, defensores a ultranza del barroco, adquirían el tono más virulento. ${ }^{\text {Él }}$ mismo se hacía un blanco fácil de la diatriba y el escarnio público, ya que desde su posición de pintor y poeta pretendía, osadamente, ejercer la arquitectura motu proprio, sin contar con estudios formales ni mucho menos pertenecer a la academia. Sin embargo, no olvidemos tampoco que la persona artística de Tresguerras, lo mismo que la de Tolsá y M anzo, es una expresión paradigmática del "artista total"

I. Francisco Eduardo T resguerras, 0 cios literarios (estudio introductorio y notas de Francisco de la M aza), M éxico, U niversidad N acional Autónoma de M éxico, Instituto de Investigaciones Estéticas, 1962. El manuscrito original hoy se encuentra depositado en el Fondo Reservado de la Biblioteca N acional. 
ilustrado: transitó con fortuna y desparpajo por todos los ramos artísticos, ya nobles o mecánicos. Y sumó intereses y aficiones típicamente enciclopédicos: coleccionista, conversador, músico y compositor, cartógrafo, ingeniero hidráulico y de caminos, agrimensor y, comprometido con la prosperidad regional, síndico del ayuntamiento. Este esmerado trabajo a tinta, a plana entera, repito, me parece con mucho el autorretrato más sugestivo: por su carácter íntimo y su espíritu apesadumbrado, nos revela a un Tresguerras diametralmente opuesto a la imagen protagónica y ufana que hasta aquí le conocíamos. Se trata, en términos genéricos, de una ventana al "taller del artista" rara vez abierta al espectador, y más de una forma tan explícita, en el contexto del arte hispanoamericano de antes y de ese momento. ${ }^{2}$

Este hijo de padre cántabro y madre criolla nació y pasó la mayor parte de su vida (I759-1833) en la pequeña ciudad de C elaya - transitado enclave agrícola de doce mil habitantes- y sólo se apartó de ella durante una prolongada estancia, en su plena juventud, en la opulenta y rival Q uerétaro; además de otras salidas, muy breves, a las ciudades de M éxico, San M iguel, Valladolid, Guanajuato y San Luis Potosí. Y, no obstante su itinerario "marginal" y su condición autodidacta, es también, hasta donde sabemos, el primer artista americano que narra en forma espisódica o al egórica "su vida", lo cual, como veremos, lo coloca en una de las fronteras de arranque del arte moderno de M éxico: pese a su anclaje en buena parte de la vieja cultura virreinal, tan sólo el decidido cultivo de la autobiografía y del autorretrato le conceden de sobra ese derecho.

\section{El Sueño verdadero o el autor soñando}

Con su peculiar dibujo nervioso y rayado, Tresguerras nos trae a la vista una escena nocturna donde aparentemente la imagen del artista, inmerso en su modus operandi, es el tema central (figura r). En aquel rincón casero, improvisado de sancta sanctorum, tan sólo compuesto por una mesa "desgarretada y

2. Al menos para el caso del arte novohispano tendríamos que citar los conocidos autorre tratos de Echave O rio, Juan Rodríguez Juárez, Ibarra ¿o Cabrera? Se trata de efigies señeras pero un tanto neutras de la condición del artista; por otra parte, los "talleres de San Lucas" 0 al guna escena de series de castas nos evocan el obrador pictórico y por ende el modus operandi del artista. En ambos casos puede palparse, aunque de forma tímida, un reflejo del correspondiente al egato que mantenía el gremio de los pintores para reivindicar la nobleza de su arte. 
DOI: http://dx.doi.org/10.22201/iie.18703062e.1998.73.1817

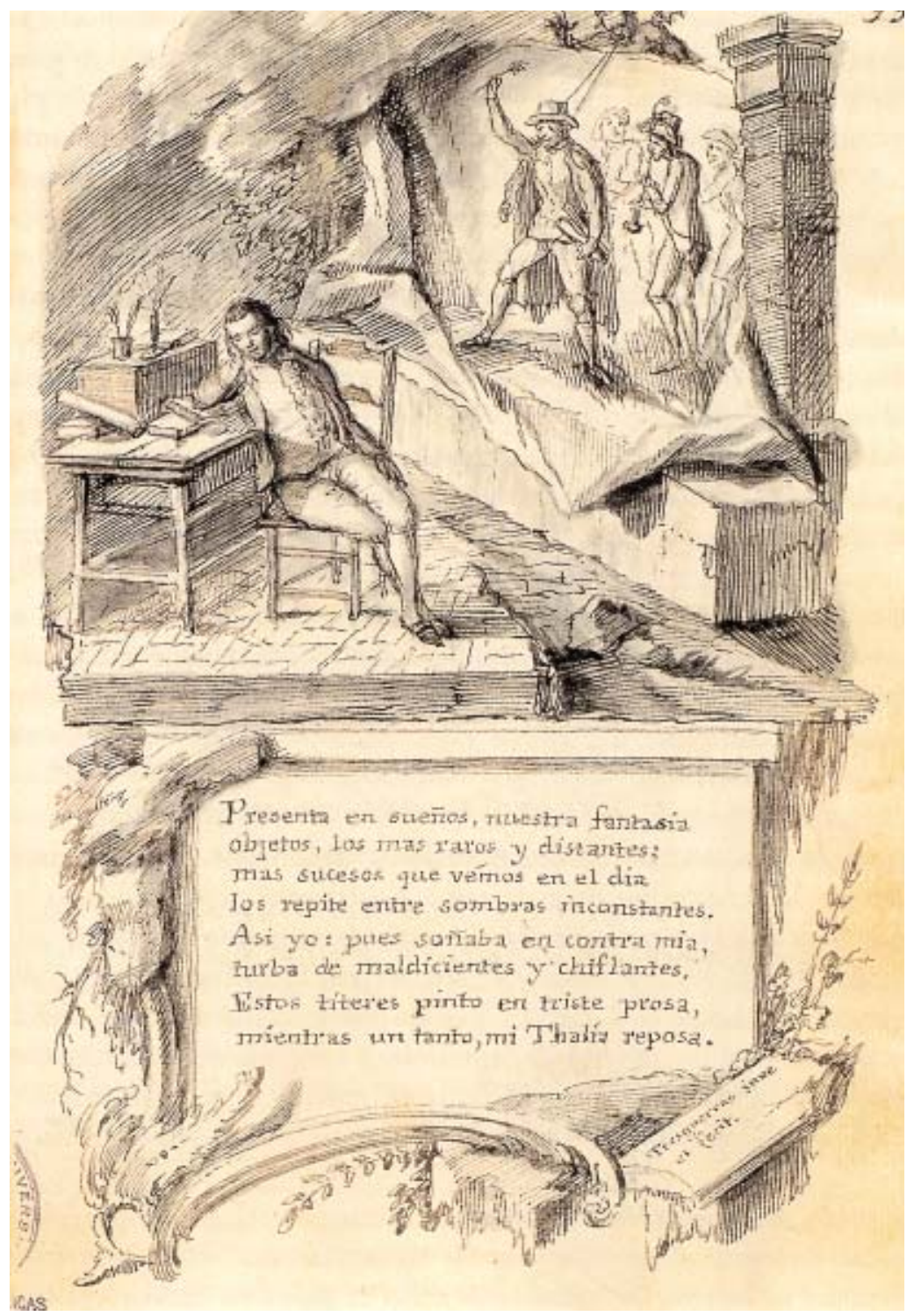

I. Francisco Eduardo Tresguerras. El sueño verdadero, 1796 (tinta sobre papel), Fondo Reservado de la Biblioteca N acional-un AM . 
bailarina" y un cajón a modo de escribanía, le hallamos meditando a la luz de una candela mortecina. Se ha recogido, solitario, en ese modesto gabinete di studio justamente para matar el ocio y discernir, con ayuda de la pluma, los avatares de su vida. Pese a su complexión joven y robusta, el autor nos asegura que se encontraba aquejado de "hipocondría", por lo que arrimó su "esqueleto" a una silla en cuyas "canillas de palo" reposaba, dice, "el nada muelle y escaso migajón de mis dos pacientes posaderas". ${ }^{3}$ En esa actitud reflexiva y entregado a una vigilia que finalmente se vuelve duermevela, prosigue, "embutí un codo entre los montados muebles y, con la mano en la mejilla (sin ser Arlequín o la D ama Triste), engañaba el tiempo y mi pachorra se satisfacía". El cuerpo del artista tomó, entonces, una posición diagonal que terminaba con las puntas de sus pies cruzados. Era evidente que el gesto adoptado subrayaba la súbita aparición, termina, de "mis pensamientos melancólicos". Escuchémosle:

Pero he aquí, que apiñados mis pensamientos como moscas a la miel ni aun la cabeza dejaban de rascarme; melancólicos eran los más, porque una luz, a cada instante me daba las buenas noches, presentaba con los pocos interrumpidos amagos de curiosidad sus últimos vales, formando un retrato fiel de nuestra fugaz y perentoria vida. ${ }^{4}$

Tresguerras se ha servido de una tradicional alegoría de vanitas - muy frecuente en la pintura barroca de tema penitencial con propósito moralizador - donde la contemplación de una vela expirante (metáfora del sentimiento efímero de la existencia) va emparejada con el estado melancólico a que le induce el ocio o el sopor y que no tarda en manifestarse, al fin y al cabo, en una profunda tristeza o depresión. Y atrapado en ese límite confuso que se tiende entre el sueño y la fantasía, emerge de su imaginación una turba de engendros monstruosos que le anuncian la vecindad de la M uerte:

A mi vacilante imaginación se le amontonaban las tristes ideas $\mathrm{y}$, todas atropadas, querían en lugar delantero. M i lúgubre fantasía bailaba infinidad de figurillas y monicacos, lisonjeándose de poner en solfa a los Endriagos, V estiglos y Entes de razón. A gatas el entendimiento, en cuclillas la memoria, la voluntad 
jugando a casitas de alquiler y todo el mecanismo de mi caletre semitonado: gracias al apetecido ladrón de la mitad de la vida y propio ensayo de nuestra última inevitable escena, me fui quedando dormido. Lo aseguraría la inacción de mis miembros, mas una funesta pesadilla dio al través con todo y desmintió señales tan poco equívocas de mi transporte.s

Fiel a su admirado don Francisco de Q uevedo, Tresguerras ha establecido una paráfrasis del postrer Sueño de la muerte empleando un vehículo introductorio semejante; el autor ocioso ha sido presa fácil de sus pensamientos tristes e inconscientemente, con la marcha de las tres potencias (entendimiento, memoria y voluntad), se ha quedado dormido. ${ }^{6}$ Este preludio mental le permite acceder al inframundo, dar rienda suelta a la fantasía y contemplar un redivivo Retablo de las maravillas, por el que desfilan los más grotescos e insólitos personajes. Con su mente agolpada y confusa, el autor no sólo es víctima de sus "ruines pensamientos" - como diría Q uevedoque le sumergen en la soledad o le hacen "lisonja a mi melancolía", sino también se vuelve blanco de las provocaciones e injurias que le lanzan los agresivos actores de "una comedia" infernal que así, de forma involuntaria, ha comenzado a presenciar.

En lugar del contingente quevediano de médicos, boticarios, cirujanos, barberos y otros mequetrefes en achaques de salud, ahora aparecen sus más renombrados enemigos precedidos de una comparsa "de fantasmas,

5. Ibidem.

6. Nótese que el parangón de T resguerras con el pórtico del Sueño de la muerte conserva el mismo carácter al egórico: "Están siempre cautelosos y prevenidos los ruines pensamientos, la desesperación cobarde y la tristeza, esperando a coger a solas a un desdichado para mostrarse alentados con él (propia condición de cobardes, en que juntamente hace ostentación de su malicia y de su vileza). Por bien que lo tengo considerado en otros, me sucedió en mi prisión, pues habiendo (o por cariciar mi consentimiento o por hacer lisonja a mi melancolía) leédo aquellos versos que Lucrecio escribió con tan animosas palabras me vencí de la imaginación, y debajo del peso de tan ponderadas palabras y razones me dejé caer tan postrado con el dolor del desengaño que lé, que ni sé si me desmayé advertido o escandalizado." Luego de leer, a modo de epígrafe el poema de Lucrecio (D e rerum natura) y los lamentos de Job, prosigue Q uevedo: "Entre las demandas y respuestas, fatigado y combatido (sospecho que por cortesía del sueño piadoso, más que de natural), me quedé dormido. Luego que desembarazada el alma se vio ociosa sin la traba de los sentidos exteriores, me embistió desta manera la comedia siguiente, y así la recitaron mis potencias a oscuras, siendo yo para mis fantasías auditorio y teatro." Francisco de Q uevedo, Los sueños (introduccción y notas de J. A. Álvarez Vázquez), M adrid, Alianza, 1983, pp. I77-I79. 
quimeras, y duendecillos guiados por dos faunotes [...] que me miraban con unos ojos neronianos y en cuyos pálidos y azorados rostros se veía, con gesto terrible, copiada puntualmente la $M$ aledicencia".7 En el dibujo correspondiente vemos cómo tales seres capriformes, conservando sus vestimentas y atributos laborales, encarnan en la persona de los siguientes personajes: Chepito el Zapatero, un trompeta del regimiento borbónico acantonado en Q uerétaro que se distinguía por soplar "un flatoso instrumento cuyo horroroso sonido influía cierto furor diabólico en sus secuaces" y el archiodiado Felipe Suasnávar (también Ilamado en forma degenerativa Suasnabo o SoezNabar), gran señor de los cagatintas de Q uerétaro y tenido a sí mismo por jurisconsulto, por lo cual se halla "cargado de cartapacios infames [enarbolando] una pluma teñida siempre con la sangre de sus hermanos". ${ }^{8}$

En efecto, en un segundo plano vemos cómo ha caído una cortina, semejante a la de un rompimiento de gloria, y sobre un entarimado guarnecido de una pilastra (que sugiere un aforo), irrumpen con estrépito cuatro personajes, dos de los cuales, amenazantes, pueden reconocerse como los arriba citados. El flatulento monsieur Chepitt, el rabioso Suasnávar, pero más atrás se suman el Cojo Romero renqueando con su pata de palo y un homosexual tildado de "joto pitiflor", al que más tarde Tresguerras llamará Filandro (es decir, el hombre que es amigo de su propio sexo). D esde las alturas un demonio insufla con su aliento los ánimos de esta cuarteta de "patulecos" (es decir, que caminan como patos), que integran una especie de mojiganga a lo faceto a cuya cabeza, conforme al texto, revoloteaba la personificación ponzoñosa de la Envidia, gozándose todos cada vez que ella agitaba su cabellera de serpientes:

Era la al gazara y desconcierto general a aquella turba infeliz; habíasele calentado, no la cabeza, sino la lengua. Siguieron luego acelerados, a una vieja renegrida, enjuta y feroz, que arrancado con elección uno de sus venenosos cabellos, lo arrojó hacia la multitud y entonces una pasión desordenada rebozaba en sus corazones, que cuanto le sobró para ser odio, le faltaba para ser desesperación. Alecto, la misma Alecto (la más terrible y temida de las Furias, espíritu del odio, la venganza y la envidia. $\mathrm{N}$ ota de $\mathrm{F}$ rancisco de la $\mathrm{M}$ aza), les cedió, el primer lugar, ni las otras Furias creían de provecho sus humosas teas, los tronadores azotes. La

7. T resguerras, op. cit., p. 59.

8. Ibidem. 
Envidia era aquel abominable monstruo; el grande Alcides ( $\mathrm{H}$ ércules. $\mathrm{N}$ ota de $\mathrm{F}$. de la M .) sólo la juzgó despojo de las Parcas.9

Por paradójico que parezca, si a Tresguerras no lo hubiera atacado el monstruo de la Envidia con tanto encono, seguramente no hubiera pasado a la posteridad sumando la fama de escritor y poeta. Como vida paralela del beligerante Cellini, las tres cuartas partes de sus manuscritos están enderezadas en contra de sus atacantes a los que nombra, significativamente, "eruditos avioletados". A tal conflicto, y a la peculiar agudeza de ingenio, el artista también debe su prestigio, aunque no reconocido, como uno de los mejores satiristas de M éxico. Este adalid del clasicismo abajeño combatió cuerpo a cuerpo a ese monstruo calamitoso y finalmente lo venció, pese a la ferocidad de su cortejo canino: un perro rabioso y mordelón, mascota preferida de la Envidia, que en aras de la posesión de un hueso ajeno es capaz de sangrarse el propio hocico. En otro de sus mejores dibujos a tinta la Envidia es una gran señora apergaminada que azuza y pervierte a sus rivales queretanos y, para representar moralmente los efectos autocorrosivos que provoca este vicio incubado en el corazón de los hombres, el artista ha compuesto un emblema triplex a plana entera todo contenido en un capriccio rococó de vetusteces tectónicas (figura 2). Allí se ve a una anciana tirada en un erial, de vientre abultado y senos fláccidos, de piel herrumbrosa y boca amoratada, que se desprende uno de sus cabellos-serpientes (símbolo de sus malos pensamientos) para arrojarlo con un ademán de furia y rencor. Es una figura que practica la autofagia tal como la describe 0 vidio'o y la sistematizó la emblemática de Alciato ${ }^{\text {II }}$ y, sobre todo, el Theatro moral de la vida humana (ı6o6) de 0 tto Vaenius (de gran influencia en la N ueva España): se muerde su propia mano, o se devora el corazón, para indicar que la única perjudicada por sus obsesiones y arrebatos es ella misma. ${ }^{12}$ La Envidia también es inmortal como la Hidra, que se multiplica cada vez que le cercenan sus cabezas; y así goza y goza con las desgracias ajenas pero, cuando reina la vir-

9. Ibidem, pp. 59-60.

Io. Publio O vidio N asón, Lasmetamorfosis, M éxico, Porrúa, I977, libro II, cap. XI.

II. Andrea Alciato, Emblemas (edición y comentario de Santiago Sebastián), M adrid, Akal, I985, pp. I06-107.

I2. Santiago Sebastián, "T heatro moral de la vida humana, de 0 tto V aenius. Lectura y significado de los emblemas", en Boletín del M useo e Instituto Camón Aznar, vol. XIv, Zaragoza, 1983, p. 55 . 


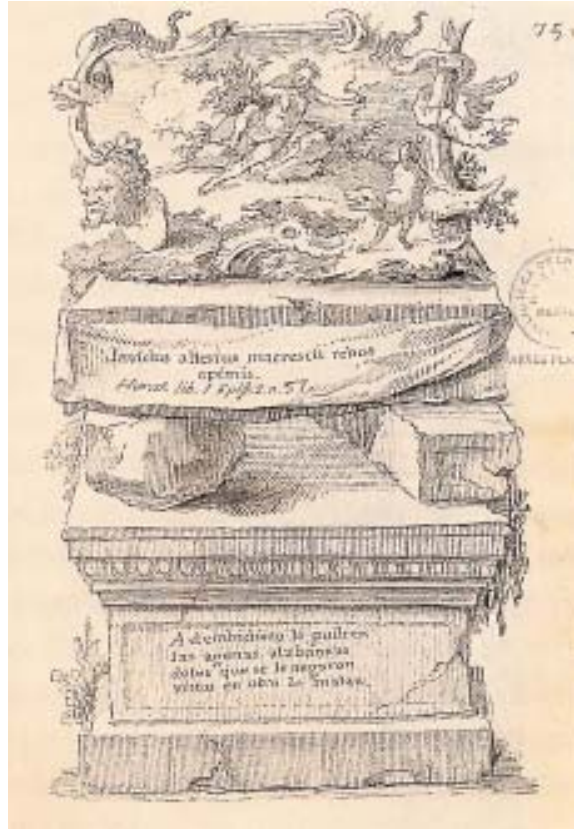

2. Francisco Eduardo T resguerras. La envidia, 1796 (tinta sobre papel), M useo $\mathrm{N}$ acional de Arte-INBA.

tud, se alimenta del propio pus que excreta, consumiéndose a sí misma.

Prosigamos con el argumento del "sueño ficticio". Aún no se reponía Tresguerras del efecto de aquella "visión tan extraña" - la fantasmagórica aparición de la Envidia— , cuando advirtió, pasmado, que esa:

[...] retostada y maldita vieja me señaló por objeto de sus iras, y que toteando (echaba lumbre por la boca, $\mathrm{N}$ ota de $\mathrm{F}$. de la M .) a la ladradora chusma, abriendo su macilenta boca, casi desencajaba sus obtusas y descarnadas mandíbulas al dar un horrendo alarido, por seña de embestir, y aquella malidicenta turba, como una arrebada inundación, que a nada perdona, se venía hacia mí entonces inculcado (en sentido de "apretar", N ota de F. de la M.) y herido ni pude hurtarme del endiablado estropeo; bien que interiormente me consolaba, pues reflejé ("reflexioné", N ota de F. de la M .) que mis enemigos eran todos envidiosos, y sin duda de lo que poseía y a ellos se les había negado. ${ }^{13}$ 
Azuzados por la Envidia, los cuatro enemigos se excitaban entre sí profiriendo imprecaciones al punto de emprenderla físicamente en contra de Tresguerras. Ante el peligro de resultar linchado, Tresguerras se despierta de súbito y, todavía confuso, no distingue las fronteras entre la pesadilla y la realidad. En su afán de librarse de los golpes, el arreciamiento de una tempestad nocturna y sus relámpagos y estruendos vinieron a conjurar definitivamente aquel ensueño angustioso y todo su entorno maléfico poblado "de chatos y bocones avechuchos". Acto seguido, ya en estado de alerta, el autor se santigua:

[...] haciendo no una cruz, sino trescientos mil Calvarios, rezando otros tantos ensalmos, y hecho adivinanza entre saludador (embaucador que cura con la saliva 0 el aliento), químico y vieja curandera, toda la empleé en tal operacioncilla, sin que volviese a soñar, que fue gracia y prueba de buen efecto de los entreverados medicamentos. ${ }^{14}$

H asta aquí la narración del "sueño" que compete a la ilustración de marras. N otemos que en otros pasajes Tresguerras ha identificado previamente la catadura de sus enemigos con personajes extraídos del Bosco y de Jacques Callot pintándolos deformes y caprichosos; asimismo, ha convocado alrededor suyo todo género de seres fantásticos como aquellos "chatos y bocones avechuchos" que habitan las tinieblas del paraje. Adviértase, de nuevo, la dimensión nocturna de la escena, la posición meditabunda de nuestro personaje, la luz exánime y simbólica del candelero y la proliferación mental de multitud de engendros agoreros. Ciertamente la conjunción de todos estos elementos enlazan al autorretrato con otra vieja tradición iconográfica presente de modo reiterado en el tardo Renacimiento, pero que el romanticismo exaltaría de nuevo: la personificación de la melancolía "de autor".

En la reelaboración de este tópico es obvio que Tresguerras no camina solo ni mucho menos lo hace con un carácter precursor en la propia N ueva España. Tampoco bebe en una sola fuente ni parafrasea a un autor en exclusiva: en "su" Sueño verdadero convergen tanto los lugares comunes relacionados con el tema como los destellos de una novedosa sensibilidad, tan personal como partícipe de las inquietudes artísticas de su tiempo. Los siguientes párrafos buscan dilucidar el origen de todas estas convergencias plásticas y 
literarias que de paso preludian, si no es que afirman, tres conceptos de modernidad en la mentalidad artística de la N ueva España: Ia asunción plena del estatus "intelectual" del artista, merced al autorretrato, y por ende la autobiografía, como mecanismo de exploración psicológica o crítica; el triunfo de su individualidad profesional (ya sin nexos corporativos y fuera de duda "su nobleza"); y, sobre todo, la floración de una subjetividad dada por la experiencia cotidiana y expresada por distintas vías genéricas. Todo lo cual antes eran dimensiones de la personalidad y la emoción que rara vez cristalizaban en las obras mismas y que, por lo tanto, permanecían vedadas al conocimiento histórico del arte de la N ueva España.

\section{El soñador: sus motivos literarios}

Guiado por la figura de Francisco de Q uevedo - cuyos imitadores en el siglo xviii se cuentan por decenas- , y del brazo de otros de sus coetáneos peninsulares (Torres V illarroel, Iriarte y C adalso), el inquieto celayense ha gustado contemplarse en el archiconocido papel "del autor soñando".

D e la misma manera que el inmortal Q uevedo, el abate Diego de Torres de Villarroel (1694-1770) también se había servido de un sueño - que le asal taba traicionero- para luego introducir sus Visiones y visitas [al infierno de la] Corte (1728). En cada uno de los tableros de esta trilogía por el inframundo, el piscator Torres evoca un "preámbulo del sueño" donde reconocemos semejante cuadro de atributos y circunstancias: la luz efímera de una bujía parpadeante, la idea de que el sueño no es sino la imagen premonitoria de la muerte, la invasión de la melancolía como "aviso de nuestro frágil ser", la huida de los sentidos y de las potencias que precede al imperio de la fantasía y su correspondiente legión de figuras bosquianas. No podía faltar el típico desplante melancólico previo al sueño: "C rucé los muslos y de bruces sobre los brazos, doblé la cabeza encima del hombro, solicitando con esta postura conciliar, si no los arrullos del sueño, los cariños de la suspensión."Is

I5. En su "preámbulo al sueño" así se retrataba este excéntrico profesor de matemáticas salmantino: "Pero con un filósofo descuido me sacudí de esta melancolía, considerando que aunque el sueño es muerte, era para mí entonces el dormir media vida [...] Con este consuelo (propio alivio de un genio perdulario) y aquella melancolía (natural aviso de nuestro frágil ser) fui perdiendo por instantes el tacto de los ojos y la vista de los otros tres sentidos y medio 
$\mathrm{N}$ i tampoco aquellos tormentos que un sillón "desjarretado" que, a modo de potro, le propina a la paciencia de sus nalgas abolladas: "disciplina de sangre". Equivalente de la expresión tresguerriana acerca del "escaso migajón de mis dos pacientes posaderas".

Es un hecho indiscutible que Tresguerras tuvo en mente los sueños torresianos como modelos de emulación, que no de copia. M ás aún sus notas personales nos remiten a ese otro paradigma de la autobiografía picaresca y frailuna: La vida, ascendencia, nacimiento, crianza y aventuras de el doctor don D iego de Torres de Villarroel de $1743 .{ }^{16}$ Una prueba indirecta de todo ello fue la inmediata acusación de "hurto" por parte de los "poetastros" ofendidos y la consecuente réplica de su autor. ${ }^{17}$ A Q uevedo y a Torres el recurso del sueño les permite establecer una distancia espacio-temporal y asistir como espectadores al "gran teatro del mundo" o, en una expresión más coloquial, a la representación "en el corral de mi cholla de la comedia" humana; y efectuaban, así, una sátira de los estamentos, gremios y corporaciones - exhibiendo simulación y abuso- y cumplir así con el propósito punzante y moralizador del sueño. Sin embargo, en ambos casos el soñador terminaba mostrándose escéptico de poder alcanzar la redención social en esta y en la otra vida. ${ }^{18}$

[...] A costada el alma, y ligados los sentidos a escondidas de las potencias, se incorporó la fantasía, y con ella madrugaron también otro millón de duendes que se acuestan en los desvanes de mi calvaria; y entre ellas se movió tal bulla, que a no ser yo tan remolón de talentos y tan modorro de sentidos, me hubiera desvelado los mismos arrullos que me mecían el letargo." D iego de Torres Villarroel, Visiones y visitas de Torres con don Francisco de Quevedo por la Corte (edición, introducción y notas de Russell P. Sebold), M adrid, Espasa-Calpe, 1976, pp. I5-I6.

I6. Vid. Diego de T orres de Villarroel, Vida (estudio preliminar, edición y notas de Russell P. Sebold), M adrid, T aurus, 1985. El móvil más importante que empujó a Torres al ejercicio de los escritos autobiográficos, según Sebold, fue justamente la "huida de la melancolía". En esto es alma gemela de T resguerras: "El lector deberá tener presente que era en esta misma época en la que T orres bailaba y tocaba la guitarra para arrojar su melancolía; melancolía que ahora sabemos era ese recuerdo de la muerte que inexorablemente nos persigue a todos. Pues, por muchas teorías del discurso que se les apliquen a los escritos de D iego, no se entenderá nunca su hondo conflicto espiritual ni la génesis de su originalísimo estilo sin tomar en cuenta que él oscilaba casi a diario entre la huida de la melancolía y la conversación con ella. [Su admiración por Q uevedo era] principalmente por cultivar la santa y saludable melancolía y así purgarse del terror que le producía su mundanidad", p. 30.

17. T resguerras, op. cit., pp. $66 \mathrm{ss}$.

I8. M ás información acerca de estos tópicos "oníricos” puede consultarse en M iguel Avilés, 
Tresguerras, por su parte, se limitaba a objetivos más personales 0 restringidos. A un tiempo que alza en su imaginación ese gran teatro mundano donde se pone un retablo de "títeres, cucarachas y monicacos" - que luego le atacan comandados por la Envidia - también se aprovecha de su estado de inconsciencia pero como tronera defensiva desde donde atisba y fustiga a la tropa sitiadora. El sueño podría ser, en términos argumentales, un mero pretexto para la apología de un artista vulnerado, de un profesor "noble" que se ha sentido calumniado o difamado por otros que no son sus pares: ignorantes, fatuos y trasnochados.

En el mismo seno de su tertulia queretana, la suya no era la única pluma que se remontaba por los mismos senderos oníricos: la de su amigo el presbítero José M ariano Acosta Enríquez (activo entre 1779 y I8I6) también urdía su curioso Sueño de sueños. ${ }^{19}$ Q uizá por ello, como bien lo notó el doctor Francisco de la Maza, Tresguerras llamó al suyo Sueño verdadero, pero también para enfatizar que, dada la saña con que procedían sus atacantes, éste no era un caso "ficticio". A este poeta y orador, oriundo de aquella ciudad, de quien un cronista anónimo dijo que era "amigo de hacer epitafios a las celebridades queretanas", se le apersonan nada menos que los mismísimos Cervantes, Q uevedo y Torres cuando fumaba una tarde de domingo apoltronado en una banca de la alameda de esta ciudad. ${ }^{20}$ A lo largo de una conversación prolija que los lleva por el cerro del Cimatario y luego a otros "países" imaginarios, sus cicerones le confían desengañados la suerte que corren la vanidad y la locura que se viven en el siglo (incorrecciones que no

Sueños fictici os y lucha ideológica en el Siglo de 0 ro, M adrid, N acional, 1981. Ya entregado este trabajo a imprenta ha llegado a mis manos, por la amabilidad de Fausto Ramírez, un título exhaustivo sobre todo este género de literatura onírica: T eresa G ómez Trueba, El sueño literario en España, consolidación y desarrollo del género, M adrid, Cátedra, I999.

I9. "Bien rellena y caliente mi cabeza con tanto acopio de zarandajas y con un surtimiento pleno de material imaginativo y fantástico, más estaba para levantarme y salir a tomar fresco que en disposición de tomar sueño; pero al cabo me rendí, y entré en el dulce reposo, que aunque imagen de la muerte es la mitad de la vida del hombre; me dormí finalmente y empecé a soñar, pero ¿cómo?" José M ariano Acosta Enríquez, Sueño de sueños (prólogo y selección de Julio Jiménez Rueda), M éxico, U niversidad $\mathrm{N}$ acional autónoma de M éxico, (Biblioteca del Estudiante U niversitario, núm. 55), 1945, p. II7.

20. Anónimo, Acuerdos curiosos, Q uerétaro, Gobierno del Estado de Q uerétaro, 1989, tomo IV, p. I4I. 
desaparecen en el más allá y se acentuán por el contrario en un diálogo de sordos); y él, a su vez, les informa de la fortuna crítica con que sus libros habían llegado hasta el presente. Si bien la afinidad entre ambos "sueños" es tan sólo genérica - el de Acosta no es una diatriba y posee un tono más irónico que mordaz- debe tenerse en cuenta que este imitador torresiano no fue ajeno al florete literario (bien conoció los manuscritos tresguerrianos y los detalles de la gresca) y, en un soneto "de saludo", el mismo año de 1796, salió en defensa de la valía de los múltiples talentos del artista de C elaya. ${ }^{21}$

Por lo que hace a sus aspectos formales, la prosa de Tresguerras comparte con Q uevedo no sólo la misma avalancha, en apariencia caótica, de adjetivos, palabrotas y dicterios sino también semejantes cualidades retratísticas. Recordemos el énfasis que ambos ponen en los rasgos grotescos de sus personajes y sus atuendos estrambóticos (igual que Acosta), que pasan de ser simples presencias para convertirse en excelentes caracterizaciones y figuras. Pese al argumento escueto y débil de los sueños, todos ellos trazan certeras imágenes dramatizadas de gran efecto plástico y esta virtud, que entonces se llamaba "anatomismo", hacía que la sátira fuera su género natural y la ironía su tropo preferido. ${ }^{22}$

\section{El amigo fray M anuel:}

heraldo del romanticismo en la N ueva España

H abida cuenta de estos motivos literarios que animan o confluyen en el Sueño verdadero, nos queda por reconocer, para el mejor examen de este mismo ejemplo, la irrupción de una nueva corriente que ya permeaba a la

2I. T resguerras, op. cit., pp. 56-57 y i86.

22. Éstas serían sus reglas: "En estas caracterizaciones parece estar presente la técnica pictórica de la anamorfosis (técnica de la descomposición de elementos y la reconstrucción por acumulación), muy apropiada para reflejar un mundo caótico y desordenado: situado en el de los sueños, libre de los elementos estructurales de tiempo y espacio, Q uevedo se afana en experimentar y construir un nuevo orden formal que permite un distanciamiento y una visión simultánea de los hechos; construye las figuras también con arreglo al especial canon estético, y en ellas acumula y superpone rasgos caracterizadores externos elaborados y ordenados de modo que resulten caricaturas simbólicas. Como en general los escritores de su tiempo, Q uevedo cultiva el principio horaciano Ut pictura, poesis en un deseo de fusionar las artes. D e ahí procede la plasticidad de sus descripciones, y tal vez la configuración de episodios aislados sin aparente orden lógico." Vid. Francisco de Q uevedo, Sueños (edición de M ercedes Etreros M ena), M adrid, Plaza \& Janés Clásicos, 1984, pp. 54-55. 
musa lírica de la élite de los poetas novohispanos de fin de siglo, aquellos que se hallaban convocados por el "periodismo cultural" del D iario de M éxico: la Arcadia M exicana. ${ }^{23}$ Éste es el caso de un íntimo amigo de Tresguerras y sin duda la voz señera del "prerromanticismo" en M éxico: fray $M$ anuel de $\mathrm{N}$ avarrete (I768-I809). ${ }^{24} \mathrm{El}$ poeta era residente en aquellas mismas fechas en el convento franciscano de Santiago de Q uerétaro, con el cargo de profesor de latinidad y, por su mutua afición al dibujo, podemos imaginarlos aún más cercanos en sus ideales artísticos. No hay que esforzarse mucho para suponer también que Tresguerras sería el confidente del fraile en sus múltiples correrías de alcoba y de su consecuente descendencia, tenida en "hijos de la Iglesia". Considerado fundador de la poesía sentimental, la obra de este cordífero de san Francisco ha sido ponderada en la historia de las letras novohispanas como un enlace "entre dos siglos y dos épocas, entre un ocaso y una alborada". En justiprecio de don Francisco M onterde, la musa de este apuesto joven zamorano de vida relajada, pese al hábito, "se mueve en una zona de incertidumbre nocturna: es el devoto lector de la clásica 'N oche Serena', a quien tortura ya, romántico anticipo, la melancolía en su celebradísima 'N oche Triste'". ${ }^{25}$ Precisamente a lo largo de sus sonetos nocturnos y "ratos tristes" se hace eco, aunque lejano, de la popularidad de Young y su mundo fúnebre y neogótico, y por efecto de su intuición pasa de ser un bucólico candoroso a un vate atormentado y "meditador ante la luna". Confidente de sí mismo, en sus creaciones elegiacas "nos ofrece su dolor en jirones" por lo que, en la misma agonía novohispana, apunta como "heraldo" de la poesía sentimental. Si bien estas notas fueron apagadas por la abrumadora persistencia de los temas de campiña arcádica (escenario idealizado luminoso en el que retoza un coro de zagalejas, pastores y ninfas), no debe olvidarse que en su última época - murió prematuramente a los cuarenta

23. Sobre este movimiento que cristalizaría a partir de su fundación en i8os puede verse Anastasio de 0 choa y Acuña, Poeśas de un mexicano (selección y prólogo de M auricio M olina), M éxico, Estanquillo-Literario, Instituto N acional de Bellas Artes, 1987.

24. D os colecciones accesibles de sus obras pueden leerse en $\mathrm{fr}$. M anuel de $\mathrm{N}$ avarrete, Poeśas profanas (prólogo y selección de Francisco M onterde), M éxico, Universidad N acional Autónoma de M éxico (Biblioteca del Estudiante U niversitario, núm. 7), 1939, F. M anuel de $\mathrm{N}$ avarrete, Entretenimientos poéti cos (prólogo de Porfirio M artínez Peñalosa), M éxico, Porrúa, (Colección de Escritores M exicanos, núms. 93 y 94), I99I.

25. Francisco M onterde, Cultura mexicana ("N avarrete en el prerromanticismo"), M éxico, Intercontinental, 1946, pp. 9I-II8. 
años y era nueve menor que Tresguerras- se acentúa "la melancolía, el énfasis, la inclinación a lo macabro, la ternura llorosa, sentimental, la preferencia por lo nocturno, lunar: paisaje adecuado para meditaciones y confidencias íntimas". ${ }^{26}$ Basta una mirada a los "Ratos tristes" ("El destino", "M i retiro", "El ensueño") o el "Sueño alegórico", para que la mente se interne por la espesura de un bosque nocturno poblado de cipreses, lápidas y sombras, y donde, además, se escuchan las tribulaciones y lamentos de M elpómene desengañada.

Sólo el fúnebre canto

con que pasan la noche búhos roncos,

melancólico suena,

esparciendo el espanto

entre caducos troncos. ${ }^{27}$

Por supuesto que $\mathrm{N}$ avarrete es otra víctima propicia para que lo asalten las ficciones del sueño. El acto de dormir es también, paradójicamente, un medio que le permite alcanzar la única certeza en el mar de confusión en que se mueve: el sueño es la imagen más próxima de la muerte que tenazmente le acosa. El siguiente autorretrato mental, espigado en tres de sus "ratos" y el "sueño", puede hacerse extensivo al de su amigo Tresguerras no sólo por la similitud de expresiones y caracteres sino porque se trata de sendos reflejos mentales de la llamada melancolía sublime o "del autor".

\section{Olvidado jay de mí! de los mortales \\ en mi triste aposento \\ me consume interior desabrimiento.}

Parece que mi triste sepultura

me adelanta la muerte

en esta melancólica clausura.

¿Q ué me queda jay dolor! si el blando sueño, 
recurso un tiempo en la tristeza mía, ya no viene a mis ojos atenuados con el rostro risueño que alegraba mi triste fantasía?

U na sombra funesta, que levanta la horrenda hipocondría. ${ }^{28}$

La cabeza reclino, y entretanto me salta el corazón dentro del pecho. Cierro los ojos; hiéreme el espanto. Diligencias ninguna es de provecho para aliviar mis miembros fatigados, mi espíritu flaquea con tantos pensamientos atropados. ${ }^{29}$

En suma, compartimos la misma opinión del maestro Monterde: el fraile $\mathrm{N}$ avarrete es al final de sus días un prerromántico íntimo y no el poeta bucólico que todos aplaudían; y por lo cual el grueso de sus Entretenimientos poéticos debe situarse a caballo entre los extremos de la "afectiva suavidad de M eléndez Valdés y la melancolía y el desencanto pesimista de Cienfuegos, que anuncia el romanticismo". $3^{\circ}$

Luego de la inesperada muerte del vate, en i8o8, Tresguerras compuso un sentidísimo obituario, y lo acompañó de un idílico proyecto de cenotafio, todo como un ejercicio poético-arquitectónico de meditación funeraria. ${ }^{3 \mathrm{I}}$ Así también le dedicó un retrato oval consagratorio, premiado por las Tres G racias, para loar sobre todo al hombre sensible, al poeta que en vida, y con el hábito a cuestas, había gozado de gran apostura y galanura, y por ende de los favores sensuales de las damas y las monjas queretanas (figura 3 ). M erced a estos lances, Navarrete nos parece un seguidor fiel de una "institución" social de esos tiempos tan relajados: la del abate mundano, amigo del "cortejo" o el

28. Ibidem, "M i retiro", pp. I58-159.

29. I bidem, "N oche triste", p. I36.

3o. M onterde, op. cit., p. in.

31. En 0 cios literarios de don Francisco Eduardo T resguerras (2a. parte, I8oI-1833), manuscrito inédito, colección del M useo $\mathrm{N}$ acional de Arte, Instituto $\mathrm{N}$ acional de Bellas Artes, ff. 32-33. 


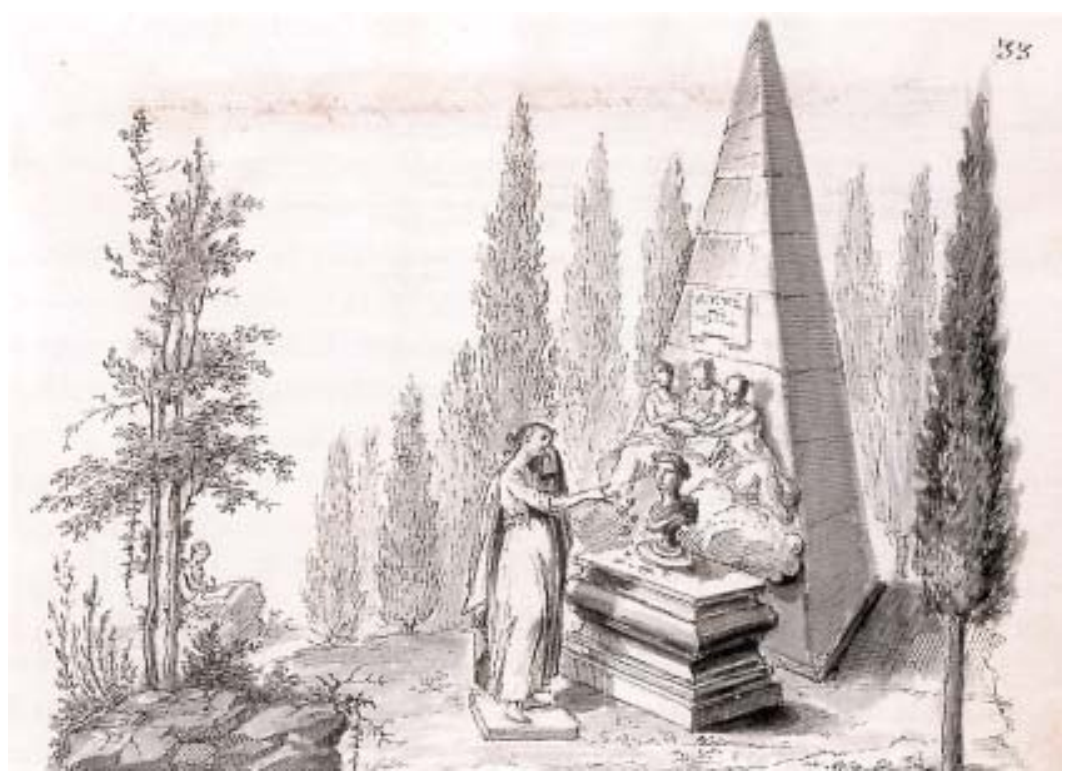

3. Francisco Eduardo T resguerras. Clorila llora en el sepulcro del poeta N avarrete, i8I2 (tinta sobre papel), M useo $\mathrm{N}$ acional de Arte-IN BA.

"chichisveo".32 Sin mostrarse del todo un ser culpígeno, nos preguntamos: ¿qué tanto pesaban sus amoríos furtivos y transgresores? ¿Q ué tanto esa situación irregular fue disparadero de su zozobra y pesimismo? Si bien se conoce que su poesía erótica estaba dedicada a mujeres de carne y hueso, ${ }^{33}$ no hay razón para negar que esta otra, la "nocturna" y meditabunda, estaría dirigida a la atribulada conciencia de sí.

32. Al respecto es ya un libro clásico el de C armen M artín Gaite, U sos amorosos en el dieciocho en España, Barcelona, Anagrama, 1987.

33. Los documentos más comprometedores que desdicen "la leyenda blanca" del fraile fueron publicados en 1940 por don M anuel Toussaint, en un artículo para la Revista M exicana de Literatura que se llamó "N uevos aspectos de la biografía de fray M anuel de N avarrete"; ahora se puede consultar en M anuel T oussaint, O bra literaria (prólogo, bibliografía, recopilación y notas de Luis M ario Schneider), M éxico, U niversidad N acional Autónoma de M éxico, Instituto de Investigaciones Estéticas-Instituto de Investigaciones Bibliográficas, I992, pp. 513-519. 


\section{Un emblema "saturnino" y otras tintas "meditabundas"}

Tresguerras con su pincel y su pluma en mano, su escuadra y su cincel, confesaba sin ambages, como tantos otros, el credo horaciano: Ut pictura poesis erit. Ésta era una máxima que ambicionaba establecer la comunión de las artes como mover a la reflexión y la crítica por medio de las figuras naturales combinadas con las sentencias moralizadoras. En la centenaria tradición emblemática halló respuesta a sus afanes integradores. Bien se ha visto que a lo largo y ancho de las fojas del manuscrito no sólo abundan los scherzi dibujísticos sino también las citas pertinentes que aderezan, en un tono de comedia, la lectura de "sus ocios"; y esto es aún más enfático en el tomo segundo donde la viñeta se tranforma en un "emblema" o transcripción visual de los proverbios referidos, glosados con diferentes soluciones poéticas. Algunos de ellos son, además, refinados emblemas de carácter amoroso y mucho más cercanos a la plena sensibilidad prerromántica de este avezado lector novohispano de las noches de Young y Cadalso. En otro lugar he podido estudiar la relación de Tresguerras con el mundo de la emblemática y puede afirmarse que allí encontró un cauce ideal a sus inquietudes diversas. ${ }^{34}$ Sin traición a este género visual y literario, ya por entonces en vías de extinción, sus producciones "jeroglíficas" constituyen el último intento novohispano por reformular la desgastada estructura expositiva (mote-cuerpo-glosa) y sus correspondientes implicaciones simbólicas.

Por ahora conviene detenerse en un solo ejemplo emblemático que se aprecia en la parte inédita de sus manuscritos y que puede fecharse en los primeros cinco años del siglo xix.35 Aunque a su modo, nótese cómo el autor mantiene el formato triplex usual de la composición emblemática y en el cuerpo de lo que ahora es un medallón cuajado de mirtos y rosas (atributos correspondientes de la Venus intelectual y la Venus sensual), nos brinda un paisaje aldeano que sirve de teatro a un lance de desprecio (figura 4 ). El poeta-pintor enuncia primero la proposición textual y visual que va a desarrollar: "Q uéjase un amante al ver el disimulo, desdenes e ingratitud de una D ama, y ésta se gloria de su proceder." El lema correspondiente es: Blandum

34. "Un epígono de la tradición: los emblemas en los manuscritos de Francisco Eduardo T resguerras", en Filippo Picinelli y las dimensiones del arte emblemático (actas del coloquio), Zamora, M ich., El Colegio de M ichoacán (en prensa).

35. Tresguerras, $\mathrm{O}$ cios (manuscrito inédito, $\mathrm{M}$ useo $\mathrm{N}$ acional de Arte), f. 7. 
4. Francisco Eduardo Tresguerras. Blandum exilium (emblema amoroso), circa i8or (tinta y acuarela sobre papel), M useo $\mathrm{N}$ acional de Arte-INBA.

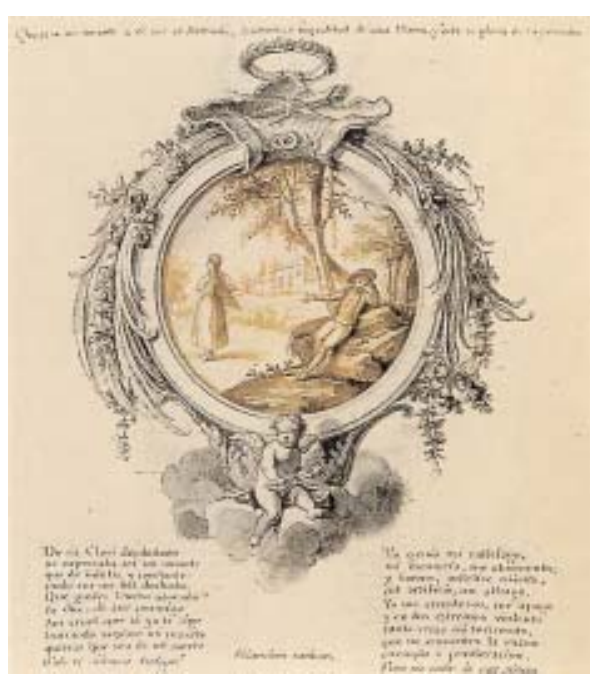

exilium (lisonja en el destierro). En la figuratio se ve a una mujer que da la espalda a su amado, mientras éste halla consuelo sentado en un roquedal y, a consecuencia de su pena, adopta la típica postura que retrata al temperamento melancólico. Se trata de una actitud gestual señalada por mantener los pies cruzados, como una forma de inacción, y también por la mano - que forma una tornapunta entre la sien y el codo- y sostiene la inclinación mórbida de la testa; dicho de otra manera, la postura del galán despechado manifiesta el efecto de pesadumbre que le acarrean los "humores negros" acumulados en la cabeza. Las décimas, a modo de glosa o comento, son una queja por la indiferencia de la bienamada y también un lamento por el tormento interno que le produce al poeta un amor no correspondido. Por eso mismo Cupido, al igual que la Fortuna, es un personaje ciego y así le vemos sentado entre un banco de nubes sin saberse el modo, el momento o el destinatario al que final mente disparará sus armas. ${ }^{36}$

36. Para conocer la variante "amorosa" de la melancolía y su descripción clínica desde la Antigüedad y el Renacimiento hasta los siglos xviii y XIX, es muy ilustrativo el estudio de Stanley W. Jackson, H istoria de la melancolía y la depresión, M adrid, Turner, I989, pp. 323340. Y sobre el origen del tema del amor como castigo y causa de pena: Edgar W ind, "Amor sacro y amor profano" y "Amor como D ios de la M uerte", en Los misterios paganos del Renacimiento, M adrid, Alianza Forma, I998, pp. I4I-I66. 


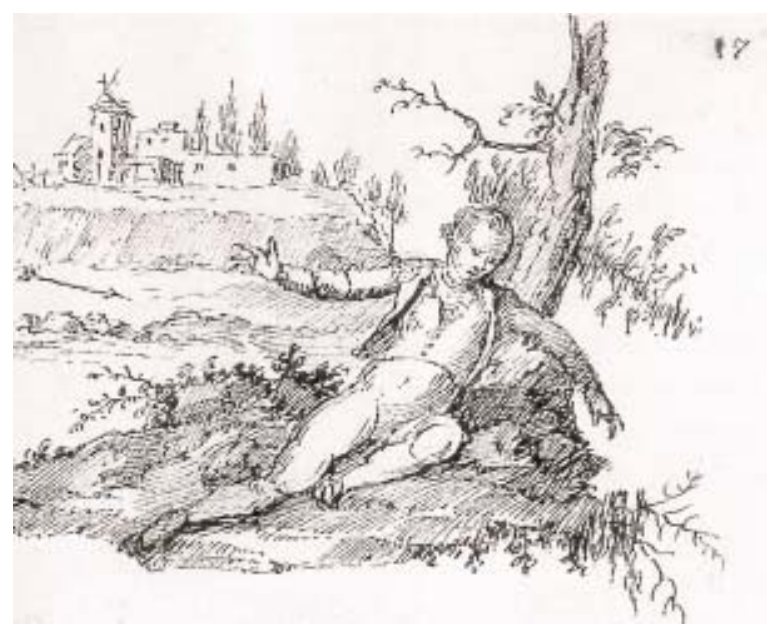

5. Francisco Eduardo Tresguerras. Relación amorosa (detalle de viñeta con posible autorretrato; tinta sobre papel), M useo $\mathrm{N}$ acional de Arte INBA.

Varias veces más Tresguerras se sirvió del mismo expediente para retratar al ente melancólico: ya en otros momentos de su poesía amorosa y pastoril, donde se le mira abatido (figura 5), o ya para resolver un cuadro de historia bíblica. ${ }^{37}$ Tan sólo hagamos pausa en una imagen muy significativa de su tiempo, la de una "maja" (entendida como figura rústica, más modesta que la vana petimetra) apoltronada en medio de un florido y acuático pensil. ${ }^{38}$ Se le ve dormida gozando de la sombra de una pérgola, acaso también del murmullo de las aguas que expele la estatua del $\mathrm{N}$ iño y el D elfín (la historia de otro amor tocado por la pena y el abandono) pero parece indiferente al tributo que le rinde el poeta (de ahí la corona floral que en esos momentos le impone Cupido; figura 6). El objeto amoroso resulta visitado por el canto

37. Por ejemplo, la acuarela que conserva la Pinacoteca de San D iego (Instituto N acional de Bellas Artes) con el tema del sueño del profeta Elías asistido por un ángel en Berseba. Vid. Francisco de la M aza, "O tra vez Tresguerras", en Anales del Insituto de Investigaciones Estéticas, núm. 32, M éxico, U niversidad N acional Autónoma de M éxico, 1963, pp. 53-58.

38. Respecto al complejo fenómeno social del majismo castellano, como estereotipo femenino o masculino de comportamiento sexual, resulta imprescindible el texto ya citado de M artín Gaite, op. cit., pp. 69-ıг2. 


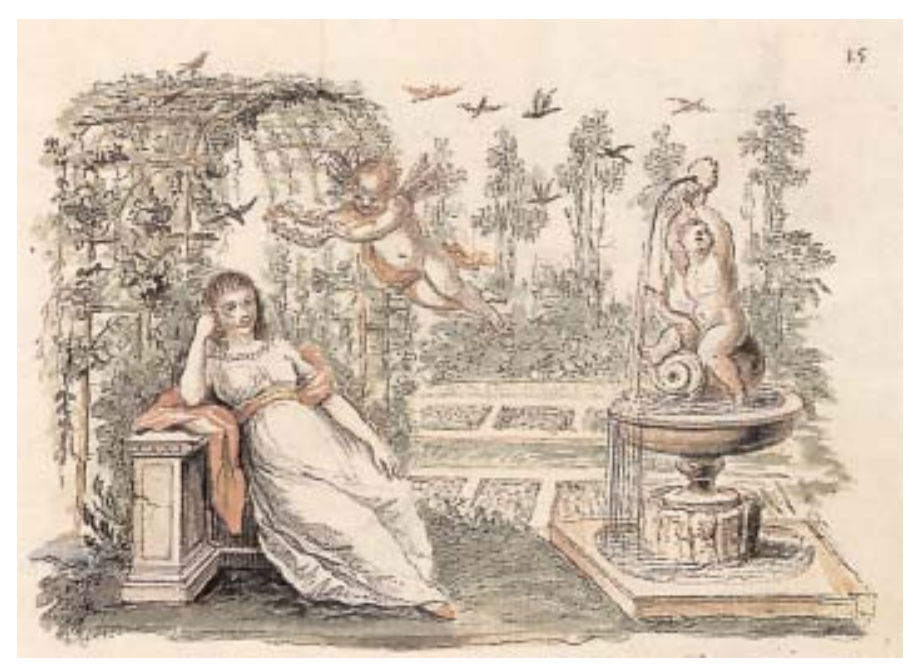

6. Francisco Eduardo Tresguerras. A Filis (maja en su recreo; acuarela sobre papel), M useo N acional de Arte-INBA.

del artista, por medio de las aves que invaden el infranqueable parterre de su "casa de placer"; los pájaros hacen el papel de mensajeros y el sueño es un mecanismo por el cual ella le entrega sus pensamientos y él, complacido, echa a volar su imaginación: las cuartetas recorren y se detienen en las perfecciones de todo su cuerpo. En todo esto se percibe la misma relación de preludio entre el sueño y la melancolía "creativa". En el anterior emblema y en esta colorida viñeta, sin embargo, también se suma un concepto paralelo e inherente al expediente gestual: la meditación melancólica puede implicar también un acto de espera o hastío, ante la ausencia del ser amado; es decir, una forma de aludir a su presencia virtual. No me parece descabellado acudir a un caso análogo y contemporáneo en el contexto hispánico que muestra las concomitancias del romanticismo en ciernes. Como expresión de desdicha y aislamiento, el joven Francisco de G oya, de forma mucho más explícita, ya se había percatado de este valor puramente emocional del acto de expectación ante la ausencia; por ejemplo, el cartón para uno de los tapices del sitio del Pardo, Ilamado La cita y fechado en I78o (M useo del Prado), se supone que cuenta la breve historia de un abandono que tal parece que nunca se re- 


\section{I08}

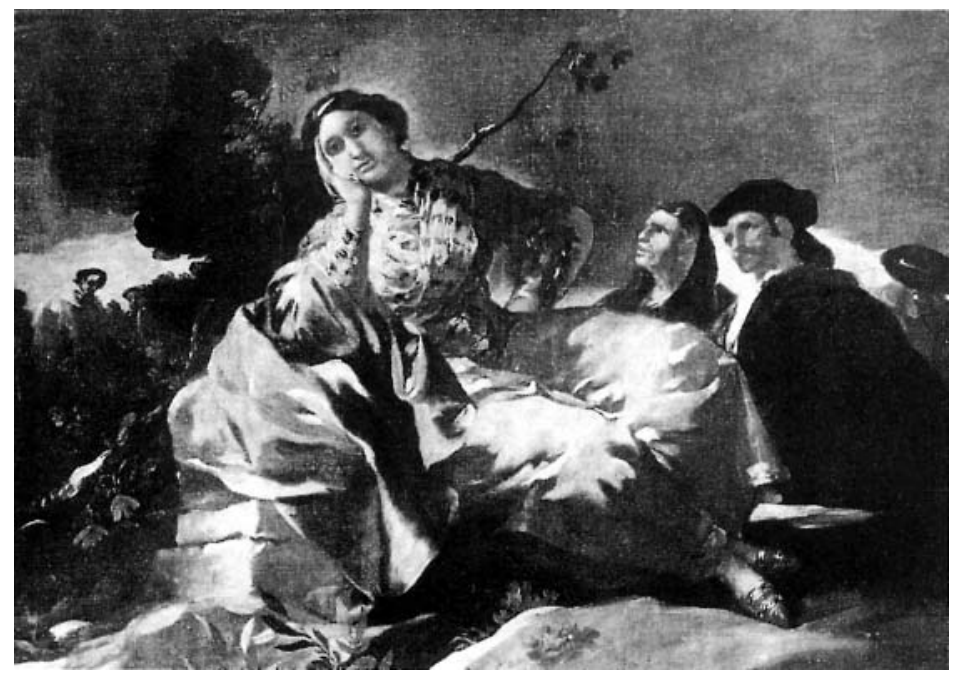

7. Francisco de G oya y Lucientes. La cita, 1780 (cartón), M useo del Prado.

suelve: la de un ser enamorado que sufre por una ausencia y que genera en el espectador una sensación inquietante. ${ }^{39} Y$ esto queda connotado por una rotunda figura femenina que en posición diagonal tiene como apoyo, real y simbólico, un basamento pétreo y ruinoso (figura 7). Un arbusto deshojado reforzaría la atmósfera de mal presagio que se cierne sobre la protagonista. Folke $\mathrm{N}$ ordström ha sugerido que el otoño y las rocas, según la Iconología de Cesare Ripa, están desde siempre asociadas a una variante patológica de la melancolía: "Se pintará sentada en un peñasco" para señalar la dureza y esterilidad a que puede conducir un exceso de "bilis negra".40 N ótese además que aflora un remanente muy signi-

39. M uy sugerentes y polémicos son los distintos ensayos sobre el "saturnismo" en Goya recopilados por N ordström y de los que me he servido: Folke N ordström, G oya, Saturno y melancolía. Consideraciones sobreel arte de G oya, M adrid, Visor, 1989, pp. r8-31.

40. Ibidem, p. 29. Cesare Ripa, I conología, M adrid, Akal, 1987, tomo II, p. 65. Recientemente se ha propuesto una relectura, más aguda, de esta escena de melancolía sombría: no se trataría propiamente de un abandono amoroso sino más bien de la personificación de la esterilidad a que conduce "el exceso de los placeres mundanos". Los majos embozados que la rondan y la presencia de una anciana cubierta por un chal configurarían una escena de celestinaje y la joven mostraría, así, el hartazgo melancólico en que ha caído por el abuso de la sensualidad. Vid. Janis A. Tomlinson, Francisco de G oya, los cartones para tapices y los comienzos de su carrera en la corte de M adrid, M adrid, Cátedra, 1993, pp. 157-160. 
ficativo de la antigua asociación de la teoría de los fluidos humorales con la astrología neoplatónica formulada por M arsilio Ficino: los roquedales o sillares de piedra no por casualidad son puntos de apoyo, lo mismo que el gran poliedro en M elancolía I de Alberto Durero, ya que Saturno dominaba al elemento tierra. ${ }^{4}$ Tresguerras en su emblema amoroso y en su maja "en el recreo" no se olvida de la prestancia que mantenía este elemento pétreo para significar, entre otras variantes melancólicas, los males que se contraen por la "depresión amorosa".

\section{v. El sueño y el capricho}

Si de emblemas hablamos tampoco se puede negar la importancia del componente textual en la serie de L os caprichos de Francisco de G oya, quien, fiel a su siglo, bien conocía los recursos de esta simbiosis formal en palabras de M uratori, recogidas precisamente por Tresguerras, de la Fuerza de la fantasía: "N ecesita de fantasía el que quiere ponerse a poeta y pintor. Estas dos artes pueden Ilamarse hermanas: la Pintura es una Poesía hecha con colores: la Poesía es una Pintura hecha con palabras." ${ }^{22}$ El artista aragonés, además, tomó de las láminas de tipos españoles los estereotipos del pisaverde, el currutaco, el manojito, el petimetre, el majo, etc., transformándolos en personajes fabulosos y esperpénticos, transitando así de la vieja sátira barroca a la nueva concepción, escéptica, de "lo grotesco" romántico. 43 Pensemos que en son de burla Tresguerras haría lo mismo con sus "avioletados" detractores: no tienen remedio y son engendros de la decadencia y fatuidad de los nuevos tiempos. H emos traído a cuento el caso del buril "literario" de Goya, tal como se aprecia en su autorretrato de L os caprichos, por parecernos muy a propósito dada la empatía de caracteres y motivos que, guardadas las proporciones, comparte con el sueño tresguerriano y su correspondiente ilustración (figura 8). Y algo que nos resulta más llamativo: no por tratarse de dos obras en buena medida auto-

4I. Bien se conocen como notables y precursores los estudios de Raymond, Klibansky, Erwin Panofsky y Fritz Saxl, Saturno y la melancolía, M adrid, Alianza Forma, I99I, pp. 279-383.

42. Tresguerras, op. cit., p. 80.

43. Para el caso de los tipos véase Antonio Rodríguez, Colección general de los trages que en la actualidad se usan en España, principiada en e año I8oI en M adrid (edición de Valeriano Bozal), M adrid, Biblioteca de Estampas Visor, 1982. Y sobre la irrupción de "lo grotesco" véase Vale riano Bozal, Goya y el guso moderno, M adrid, Alianza Forma, 1994, p. 5I. 


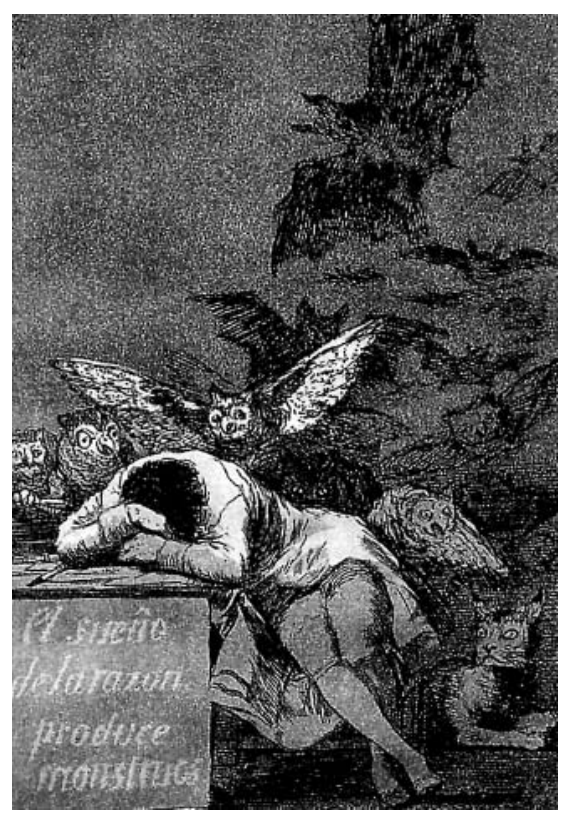

8. Francisco de G oya y Lucientes. El sueño dela razón produce monstruos (capricho 43 ), I799.

biográficas, producto de la agudeza y la condición personal, dejan de reconocer una raíz común - con un año de por medio en su hechura- en el tratamiento de varios temas recurrentes en la literatura de la época: el sueño y su inevitable fantasía, la gestación de la obra de arte y la melancolía del autor. En suma: tienen que valorarse como apuntes del genio "frente al espejo", como "cuadro de familia" de aquellos hombres que se consideraban a sí mismos, desde el Renacimiento, "nacidos bajo el signo de Saturno".

Bien se sabe que en su proyecto original Goya pensó llamar "sueños" a sus célebres aguafuertes, como una suerte de transcripción gráfica - si bien actualizada - del periplo infernal de Q uevedo. Al escoger finalmente el término "obra de caprichos", el grabador perseguía enfatizar el deseo de "desterrar vulgaridades perjudiciales" sirviéndose de la libre inspiración de la fantasía. 0 en palabras atribuidas al propio autor: "[...] subministrar materia para el ridículo y exercitar al mismo tiempo la fantasía del artífice". No era fortuita la elección del capricho número 43, que lleva por lema "El sueño de la razón produce monstruos", para presidir, como tenía pensado en un principio, la carátula de toda la serie; ni tampoco el subtítulo original: "El autor soñando." Su intento sólo es desterrar vulgaridades perjudiciales y perpetuar 
9. "Frontispicio" (grabado sobre metal), 0 bras de Francisco de Q uevedo y Villegas, vol. i, I699.

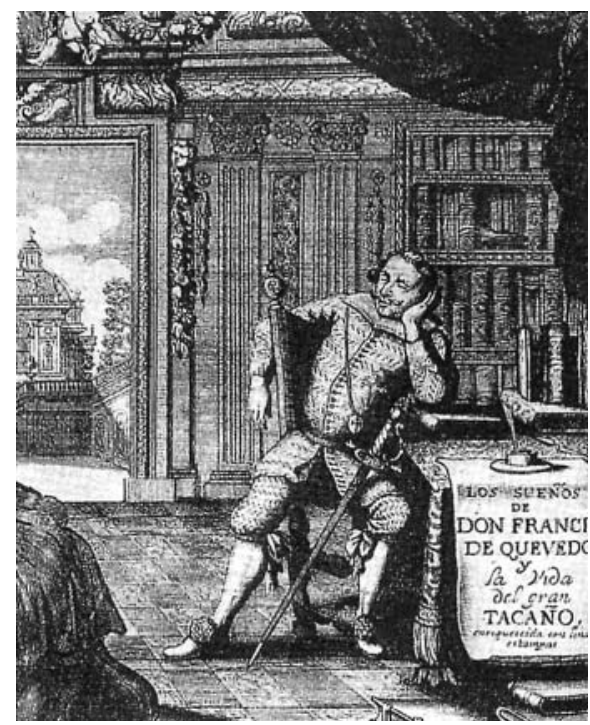

en esta obra de caprichos el testimonio sólido de la verdad" (y otra vez vemos subrayado el propósito moralizante). ${ }^{44}$ La sátira quevediana era, con sus gafas deformadoras, el giro literario más eficaz para dibujar la realidad y sus contornos contrastados. Con sobrada razón G eorge Levitine ha dado como antecedente plástico y conceptual de esta imagen la misma estampa quevediana de la edición de las obras completas de i699; ejemplar corriente que estimulara a los dos artistas no sólo para ligarse con su gran tutor intelectual sino como forma de presentación "programática del contenido" o imagen clave de toda la obra que luego le seguía.45 El espadachín noctámbulo que también fue Tresguerras bien pudo imaginarse trasuntado en la figura de su héroe literario: un galano mosquetero de capa, pluma y sombrero, defensor de su honor, pero que en ese momento ha depuesto la espada renunciando a las querellas gremiales (figura 9). Q ue prefiere entregarse a un sueño plácido, acodado en sus libros y formando la consabida tornapunta con la palma y la quijada. Este pórtico libresco corresponde precisamente a la serie de los

44. Los caprichos de Goya (introducción y catálogo crítico de Enrique Lafuente Ferrari), Barcelona, Gustavo Gilli, 1978, p. i20.

45. George Levitine, "Literary Sources of G oya, Capricho 43", en Art Bulletin, vol. XXXVII, I955, pp. 56-59. Apud Goya y el espíritu de la Ilustración (catálogo de la exposición), M adridN ueva York, M useo del Prado-M etropolitan M useum of Art, I988, pp. II4-II5 y 227-232. 


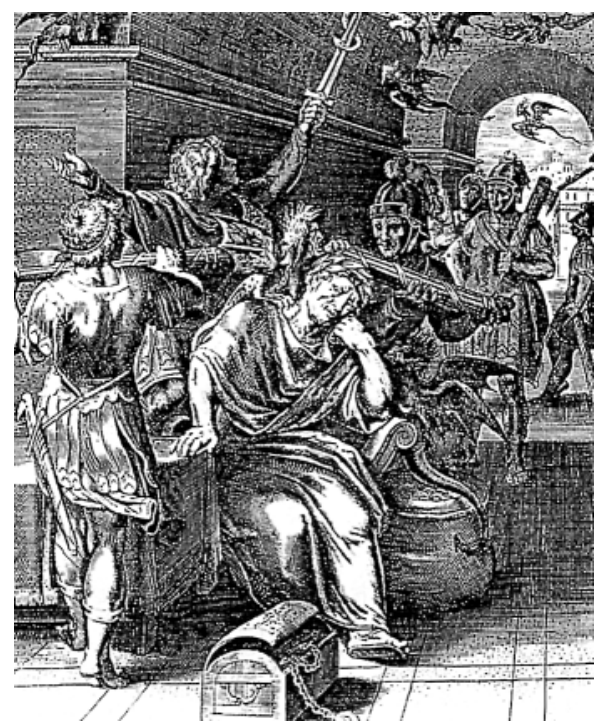

Io. O tto van Veen (Cornelis Böel

grabó). M entisinqui etudo (grabado sobre metal), T heatro moral de la vida humana, emblema 43, I606.

Sueños y es, además, un certero traslado gráfico de las propias palabras con que Q uevedo se retrata al introducir los mismos: "[...] me quedé dormido: luego que desembarazada el alma se embistió de esta manera la comedia siguiente, y así lo recitaron mis potencias a obscuras, siendo yo para mis fantasías auditorio y teatro". En otra contribución de peso, Levitine ha llamado la atención sobre otras fuentes emblemáticas que también informan tan "enigmática y equívoca" imagen del autor; ${ }^{46}$ una de ellas, que también se encontraba al alcance del artista de Celaya, debe ponderarse aquí como recurso pertinente para ambos (figura Io). Se trata del emblema número 43 del horaciano Theatro moral de la vida humana de 0 tto Vaenius (I606) que lleva por lema La inquietud del entendimiento y justamente trae a la vista la figura de un césar victorioso, distinguido por sus lauros y fortuna pero que, pese a los esfuerzos de sus guardias y ministros por disipar a sus atacantes, se ve "[...] acometido por todas partes de congojas, ansias, cuydados del govierno, que como crueles $\mathrm{H}$ arpias y Sphinxes monstruosos, hazen un exército volante de molestos enemigos, que a continuos asaltos le privan del gusto, del sueño y de la comida; y a vezes dan con él en la sepultura sin que sus

46. George Levitine, "Some emblematic sources of Goya", en Journal of the Warburg and Courtauld Institutes, vol. xxii, núms. I-2, 1959, p. I30. 
riquezas, sus despojos, sus thesoros, sus guardias y sus lictores sean parte para restituirle el desseado reposo y curarle su importuna enfermedad" . ${ }^{47}$ Los seres híbridos y alados que aturden y muerden al sujeto depresivo se interpretan como representaciones de las pesadillas y de sus propios "pensamientos obsesivos". A esos "molestos enemigos", que en su Sueño se ven aliados con el diablo, Tresguerras los llama repetidamente "endriagos", "vestiglios" y "harpías".

Artista de capricho significaba, en su proyección expresiva, atender a los dictados de la fantasía - que por lo general se cobija bajo el sueño- prescindiendo así de las convenciones de la fabricación del arte o las ataduras de la razón. La definición orteguiana sigue siendo certera: "C apricho representa todo aquello que un pintor hace al margen de su oficio." 48 Por eso al genio de Fuendetodos le vemos inactivo, envuelto en la penumbra y amenazado por una parvada de criaturas nocturnas. Pero il capriccio es algo más que un devaneo íntimo. Todo un subgénero de la pintura de paisaje, el dibujo arquitectónico, los cuadros de vanidades o los scherzi de una libreta de apuntes, reaparece, en el siglo xviii, prohijado por la individualidad emergente de los artistas y cristalizado en una nueva realidad poética. Se diría en términos más ilustrados que el artista ejerce la facultad de poner en el teatro de su imaginación asuntos y figuras de su propia invención, con objeto de escarnecer los hábitos perniciosos y las costumbres ridículas de su tiempo. Así, no obstante su concepto de originalidad esencial dado por el genio individual, como "algo no copiado", il capriccio también gozaba de una tradición específica (Callot y Tiépolo), de la que aun el mismo Goya sería un deudor genérico.49 Para Goya, Tresguerras y tantos más en el ámbito hispánico, el paradigma plástico de este "divertimiento" mitad moral y mitad satírico lo hallaban en los tableros "disparatados" de Jerónimo el Bosco. Conocían éstos bien por visita a la colección escurialense, tan apreciada por Felipe II, o bien meditando desde ultramar como Tresguerras los comentarios leídos en Q uevedo y en Torres y los más prolijos y apologéticos de fray José de Sigüenza en su historia del monasterio jerónimo y, desde luego, las de don Antonio Ponz en su leidísima bitácora de viaje que para Tresguerras fue credo estético. ${ }^{50} \mathrm{~N} 0$

47. Sebastián, op. cit., p. 24.

48. Apud Edith $\mathrm{H}$ elman, Trasmundo de G oya, M adrid, Alianza Forma, 1983, p. ı.

49. Ibidem, pp. 40 y I63-164.

5o. Para indagar en la interesante relación entre Q uevedo y el Bosco véase notas de Álvarez Vázquez en su edición de los sueños de Q uevedo (1983), p. 96. Tresguerras, por su parte, dirá 
obstante haber sido el oráculo de la crítica academicista, Ponz señalaba al Bosco como un "artista de invenciones caprichosas, instructivas y simbólicas"; en particular ponderaba el cometido ejemplar de su "extraña fantasía" al presentar - en el Carro del heno o la Creación del hombre - "Ios vicios, moralidades, avisos y desengaños" de la vida.

En suma, asociado el capricho a un programa moralizador se establecía un oportuno maridaje entre uno de los ideales de la cultura barroca y otro inherente a la preceptiva correctora de la Ilustración. No había, pues, tal contradicción entre el hecho de liberar a la costumbre ciega del error y el uso de un discurso tragicómico, con fondo fantástico o irracional, movido por los impulsos de la pasión o un simple estado de melancolía personal. Con mucho acierto Edith $\mathrm{H}$ elman ha visto que el sueño goyesco era consustancial al género empleado por los escritores que, aunque escépticos, se erigían en veedores de las aberraciones o extravagancias sociales:

En la literatura satírica, el sueño sirve de molde en el que se vierten visiones fantásticas que se parecen extraordinariamente, y mediante las cuales se revelan las absurdas creencias y acciones de los contemporáneos del autor, 0 aspectos irracionales de ciertas instituciones y usos consagrados por el tiempo. En estas obras el sueño proporciona al autor una defensa contra las consecuencias desafortunadas que podrían acarrearle la crítica o sátira social y moral que encierra la obra.sז

De aquí que G oya también adoptara un introito literario convencional que por otra parte bien se podía leer en la prensa o la folletería corriente de la época. Sin embargo, es un hecho revelado que en el capricho número 43 concurren por igual un agente interno y otro externo: al atractivo de su íntima experiencia personal de frente al proceso de la creación artística, se suma el manejo de una sorprendente hondura emblemática.

En la primera y más compleja versión del frontispicio de i797, el autor se

del aspecto de su enemigo Romero: "[...] y en verdad es de las más irregulares, ridículas y despedazadas figuras que pudo inventar Jerónimo Boscho y Jacques Callot". M ás adelante, al intentar recuperarse del Sueño verdadero y citando a Ponz como fuente "iconográfica", volverá al tema: "M edio desperté y con las manos en la cabeza huía, sin poder contenerme; miraba aún una legión de espectros, semejantes a las diablescas y caprichosas invenciones del gran Bosco, todos armados con chuzos (macana terminada en una esfera con puntas de hierro) y pesadas cachiporras." T resguerras, op. cit., pp. 4I y 60.

s. H elman, op. cit., p. I65. 
II. Francisco de Goya y Lucientes.

"Frontispicio de la serie de Los sueños (primera versión)", I797 (tinta y carbón sobre papel), M useo del Prado.

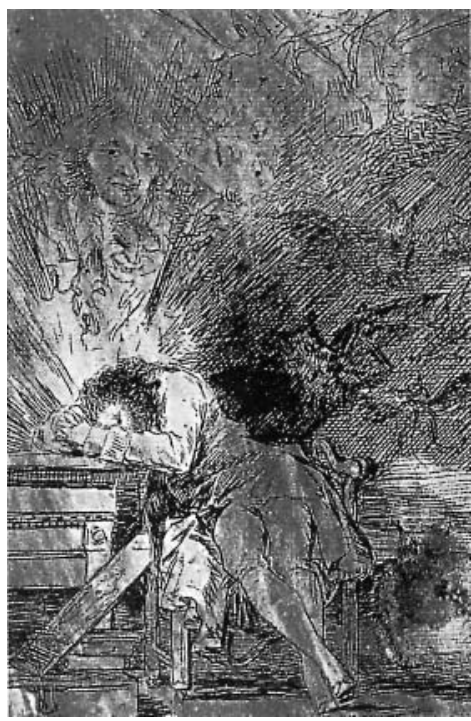

ha desplomado de bruces sobre la prensa de grabado, a cuyos pies yacen su caja de pinturas y una plancha burilada; lo mismo que a Tresguerras le vemos con los ojos cerrados y apoltronado en una silla que le obliga a mantener los tobillos cruzados (figura ir). $\mathrm{H}$ ay una correspondencia nada fortuita con la misma expresión con la que Torres dio inicio a la segunda parte de sus sueños: "Yo me vi de bruces al bufete." Un resplandor de luz emana desde su cabeza y nos permite adivinar, de entre la oscuridad de la alcoba, algunos rostros desencajados, dos autorretratos, un asno, un perro (encarnaciones de la Ignorancia y la Envidia) y una nube de murciélagos que se aproximan con el propósito de aturdirlo. Algunos logran posarse en sus espaldas. La luz es un elemento radicalmente concebido entre G oya y Tresguerras: lo que para éste es un mero motivo de reflexión significada por la vela, para aquél es nada menos la fuente de su propio intelecto e invención: para destierro de tinieblas, en un medio adverso, y renacimiento glorioso de la verdad racional..$^{2}$ En la versión final la luz pierde este protagonismo y la lechuza,

52. Para otros especialistas en Goya esta representación tiene justamente una lectura a la inversa, nada tradicional: Goya imagina y evoca el "mundo de la noche" desde su propio extravío racional, su sueño "monstruoso", y así lo "saca a la luz"; aunque se reconoce que finalmente, como toda la serie, el artista juega con la ambigüedad de sentidos. Vid. Bozal, op. cit., pp. II5-II6. 
señal de la oscuridad, lo conmina a trazar todo aquello que ella misma le dicte. ${ }^{53} \mathrm{~N}$ o obstante la deliberada ambigüedad de toda la obra, hay que confesar que allí, finalmente, como piensa H elman, cuenta la voluntad personal con que el artista concibe su obra:

El sueño, por otra parte, no es únicamente la fuente oculta de visiones y formas, sino también el impulso activo que lleva al poeta 0 al pintor, medio despierto, medio soñando, a reproducirlas en obras originales de crítica o protesta social. Y cuanto más fuerte es la personalidad del artista, cuanto más intenso su deseo de afirmación personal, tanto más deformadora y expresionista resulta la forma en que reproduce o recrea su visión y sentir íntimos. ${ }^{54}$

VI. La melancolía generosa y el desengaño ilustrado

Ciertamente la circunstancia nocturna de una escena con personificación melancólica era un lugar común en toda evocación literaria o plástica desde el Renacimiento $y$, sobre todo, gracias al insigne y hermético grabado de Alberto Durero M elancolía I. M e supongo que la oscuridad patente en el capricho goyesco venía asociada a una metáfora clínica mucho más antigua y que hunde sus raíces en la teoría humoral atribuida a $\mathrm{H}$ ipócrates y su correspondiente etiología desarrollada por $\mathrm{G}$ aleno: a toda persona diagnosticada con imaginación lóbrega o mente perturbada se le atribuía un exceso de vapor sucio (originado en la bilis negra) que le invadía la masa cerebral para terminar de hundirla en el aislamiento y las tinieblas. La gran novedad del grabado de Durero sería, entonces, la dignificación del humor melancólico como condición sublime para el acto de creación, en comunión con las teorías del neoplatonismo en boga. En uno de sus trabajos más penetrantes y eruditos Erwin Panofsky ha propuesto que M elancolía I es "en cierto modo un autorretrato espiritual", tanto por la valoración de la geometría - ahora disciplina primaria del pensamiento- como por la exaltación intelectual del temperamento melancólico, hasta entonces visto como un estigma incurable

53. U na abundante recopilación de la fortuna crítica y diversidad de lecturas que se ha dado a la obra la ofrece Roberto Alcalá Flecha, Literatura e ideología en el arte de G oya, Zaragoza, D iputación General de Aragón, I988, pp. 44I-453.

54. Helman, op. cit., p. I66. 
y temido. Nada menos se trataba de un nuevo ser "dotado de potencia intelectual", redimido de la rusticidad de las artes mecánicas y provisto, por igual, de los instrumentos de la ciencia y del poder de la imaginación. En suma, ahora la misma condición de aislamiento propiciaba la asunción de la idea del genio, el artista se hallaba tocado por un "frenesí divino" que colocaba a todos sus congéneres en situación de privilegio.55 No por ello dejó de pensarse, sobre todo en el mundo contrarreformista, que la melancolía podía degenerar gravemente y manifestarse en un "furor" patógeno y así, más allá de un perfil caracterológico, siguió siendo reprobada como desgracia psíquica u orgánica indeseable, equivalente de la abulia, la pereza, la indolencia. Pero esta "otra" melancolía intelectual 0 artificialis, pasado el triunfalismo del barroco y de la llustración, volvió a ser un signo de los tiempos, en palabras de Panofsky: "como conciencia intensificada del propio yo". Pero ahora también cargada de una insólita cualidad profética, según las ideas de $\mathrm{H}$ ugh H onour: Wrigth of Derby, Caspar David Friedrich o William Blake son, en buena medida, visionarios románticos colocados en una situación de privilegio, por encima del común de los mortales y con la facultad de desvelar los recónditos secretos del espíritu..$^{56}$

Entonces, cada quién a su modo podía ver en la luz una batalla, si bien con victoria pírrica, para restituir sus potencias a la mente. Empero, lo que para Goya en un sentido más profundo puede suponer una lucha secular entre la luz (el entendimiento del artista) y la oscuridad (representada por los cuadrúpedos y las aves nocturnas), para Tresguerras simplemente son elementos simbólicos que preceden a la aparición de sus rivales en calidad de esperpentos. Es obvio que tales "figurachos", que hacen las veces de los monstruos de la razón atribulada, no poseen ninguna carga moral explícita ni mucho menos la cultura "moderna" que permea a buena parte del aguafuerte goyesco. No obstante, concebidos con sólo un año de por medio (el celayense en 1796 y Goya en I797), ambos "sueños", si bien con un nivel de lectura diverso, corren paralelos en un caso de afinidad genérica que hoy no debe parecernos sorprendente.

Algo más los emparienta estrechamente: el significado en el modo de representación. Cuenta aparte del intrincado simbolismo que se esconde detrás de cada uno de los elementos zoomorfos (incluidos un lince que le sirve de

55. Panofsky, op. cit., pp. 239-267.

56. $\mathrm{H}$ ugh $\mathrm{H}$ onour, El romanticismo, M adrid, Alianza Forma, 1981, pp. 256-328. 
lazarillo y los búhos y gatos de mal agüero que aparecen en la versión final), G oya ha vuelto a utilizar - si bien de una forma radical - el conocido expediente icónico que retrata al individuo melancólico: en lugar de la tradicional postura sedente con la mano en la mejilla, "al canto de un bufete", el autor lo ha hecho de una forma radical y se ha tendido boca abajo reposando la frente sobre ambos puños crispados. De tal manera consigue subrayar el efecto disipador de la luz y por ende su papel protagónico de "soñador vidente".

$\mathrm{N}$ o era la primera vez que G oya abordaba el tema de la melancolía ni tampoco la ocasión en que hacía gala de sus conocimientos emblemáticos. Folke N ordström ha examinado con detenimiento al gunas de las constantes iconográficas del universo goyesco, revelando, con sugerentes hipótesis, el espíritu "saturnino", otoñal, lóbrego o negro bilioso que enseñorea no sólo la obra gráfica y pictórica sino otros avatares decisivos en el decurso de su vida emocional. Éste es un análisis del estado de ánimo que se hace extensivo al grueso de su generación intelectual y que se expresa no solamente en el arte sino en el sentimiento político finisecular: Goya sabe muy bien que vive el momento de las esperanzas ahogadas.

Lejos de ser un romántico ocurrente, Goya ha transitado por el mundo de los emblemas morales, la sátira española y la ilustración de su tiempo; y tanto en las obras de encargo como en las de satisfacción personal se adueña de un discurso crítico, que no excluye al propio de esa tradición al egórica. Sin embargo, lejos de aplicar mecánicamente sus modelos y divisas, o las estrategias del discurso punzante, según el caso, gustaba reinterpretarlos merced al ingrediente novedoso de su ingenio, ya fuere mediante su transcripción al género de la pintura costumbrista o la subversión discursiva, sobre todo patente en las series gráficas.

La doble intención de todo esto alcanza, inclusive, al retrato físico e intelectual de uno de sus más allegados, quien fue además pieza angular en el ambiente político "ilustrado": el ministro M elchor Gaspar de Jovellanos (I798). El mismo Nordström nos ha mostrado el sustrato sombrío y nocturno de la poesía de Jovellanos y su equivalente narrativo en las $\mathrm{N}$ oches lúgubres de José C adalso; asimismo, la admiración que Goya les profesaba al reconocerlos portadores de una nueva contextura cultural, que hoy hemos llamado "prerromanticismo", al menos por lo que toca al mundo hispánico. Bien se conoce el gran retrato del polígrafo y estadista asturiano que está señalado por su carácter íntimo e informal (figura ı2), en contraposición al uso acartonado de la efigie de un hombre público. $57 \mathrm{H}$ undido en la penum- 
I2. Francisco de Goya y Lucientes.

Retrato de M elchor Gaspar de Jovellanos, 1798 (óleo sobre tela), M useo del Prado.

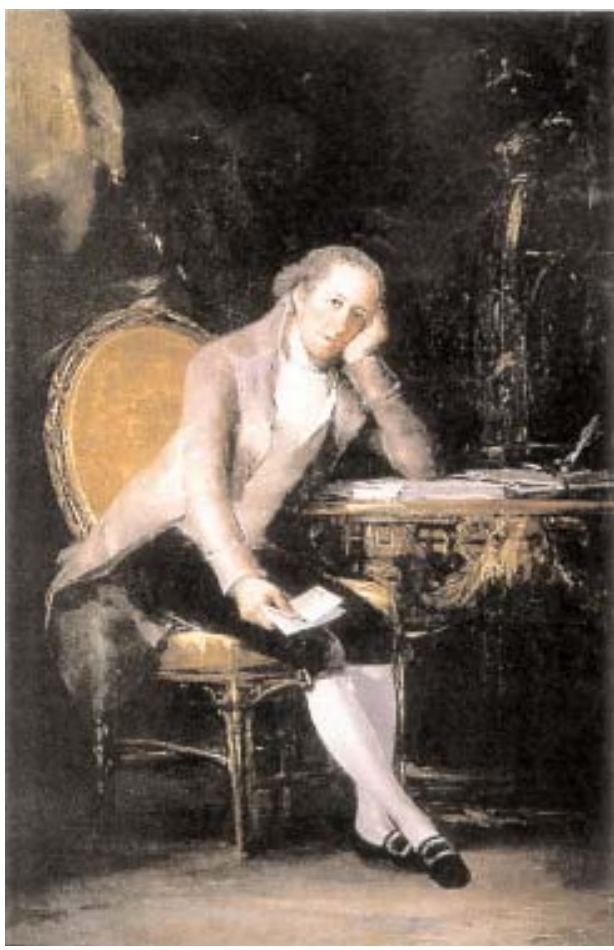

bra vespertina de su despacho de "G racia y Justicia”, "Jovino el melancólico" (así le Ilamaban sus amigos como M eléndez Valdés) se halla sentado, en reposo, con los pies formando una equis y el brazo acodado en su escritorio que, entre la mejilla y la sien, apuntala la inclinación mórbida de la testa..$^{8}$ $\mathrm{N} o$ ha faltado quien reconozca en la desgraciada trayectoria pública del personaje (exiliado y luego destituido) un presagio del sentimiento de desilusión

58. Parte de esa elegía publicada en 1797, que Levitine tiene como disparadero literario del capricho 43 por la misma correspondencia del año, dice así: "[...] T odo, todo / Se trocó a un infeliz: mi triste musa / N o sabe ya sino lanzar suspiros, / N i saben ya sino llorar mis ojos, / $\mathrm{N}$ i más que padecer mi tierno pecho. / En el hórrido trono alzó la oscura / M elancolía; y su mansión hicieran / Las penas veladoras, los gemidos, / La agonía, el pesar, la queja amarga, / Y cuanto monstruo en su delirio infausto / La azorada razón abortar puede". Levitine (1955), op. cit., p. 62. Véase también el examen positivo sobre el prerromanticismo literario de JoveIlanos, Cadalso y M eléndez en Rubén Arce, La poesía del siglo ilustrado, Madrid, Alhambra, I98I, pp. 420-47I. 
finisecular que se había incubado en la inteligencia española al constatar el fracaso de los ideales ilustrados, o de los programas reformistas saboteados por el mismo Carlos IV, o del vano intento de hacer de la razón un rectorado para el común de la vida social.

\section{Colofón}

La narración pesimista de Cadalso, tan presente en Jovellanos y Goya, no sólo anunciaba los temas sepulcrales fieles al modelo exitoso de Edward Young y sus $\mathrm{N}$ ight Thoughts sino también una desconocida sensibilidad introspectiva que será la pauta para toda una generación galvanizada por "el secular desengaño". D esde sus publicaciones tempranas Cadalso ya había hecho suyo el mal du siècle: 0 cios de mi juventud (I773), por ejemplo, tuvo el subtítulo de "alivio de mis penas" y fue escrito a impulsos de su ánimo "vencido por la desgracia" y cuyos "versos tristes le ayudan a libertarse de la melancolía insoportable en la que estaba sumido". $59 \mathrm{~N}$ ada raro era que G oya, por su parte, también buscase en sus grabados "un refugio para sus penas". EI joven e incomprendido Tresguerras, desde su exilio queretano, bien podía enarbolar el mismo título (0 cios) a modo de un solitario manifiesto estético y en descargo de su curiosidad universal. Leamos esa confesión puesta en una cuarteta:

\section{Valdés, Villegas, Cadalso, \\ Gerardo y el gran Q uevedo, \\ Ilenan mi soledad \\ sus dulces obras leyendo. ${ }^{60}$}

Junto con su amigo Navarrete no sólo imitaría, como Cadalso, los mismos ambientes que se respiran en The Complaint, or Night Thoughts on Life, D eath, and Inmortality (I747) del doctor Young, sino que los propios actos de su vida los verá proyectados, conforme al credo sentimentalista, en medio de la oscuridad que le tendía un destino incierto. Lo mismo que al infortunado Tediato, el personaje de Cadalso, la tristeza lo sumergía en el mundo 
de las dudas y asechanzas. ${ }^{61}$ Así entonces habrá que ponderar aquí el hecho más negativo de su vida profesional, el que sin duda se convirtió a la postre en drama central de su existencia, aunque también se tendrá que discutir con más detenimiento: el total rechazo de la Real Academia de San Carlos a sus pretensiones de incorporarse como uno de sus miembros, para poder gozar del título de arquitecto "supernumerario", en el año de i794; es decir, dos antes de concebir el Sueño verdadero. El no haber sido reconocido por la institución que justamente encarnaba su gran paradigma estético, el neoclasicismo que motu proprio había abrazado desde su temprana juventud, cosa que le fue constante y lastimosamente recordada por sus enemigos ("es arquitecto porque lo dijo el diablo"), fue algo más que un hecho doloroso 0 un simple desaire del autoritarismo borbónico: generó en el afectado una enorme necesidad de afirmación y, por ende, su notable fecundidad y diversidad productiva. $\mathrm{H}$ ay pruebas de que Tresguerras se sentía vulnerado y vulnerable. Pero bien puede decirse que finalmente el despecho - y el haber descreído de los valores racionales de esa institución- lo empujaron para asumirse como un "genio solitario"... aunque provincial.

$\mathrm{H}$ emos visto en otros pasajes de sus manuscritos cómo Tresguerras se lamenta de la incomprensión general a su "genio remolón" y se entrega solitario al cultivo de diversas parcelas artísticas, denostando no sólo la decadencia del gusto sino también la ignorancia y la impostura de las costumbres. Q uizá impulsado por el íntimo deseo de anegar su melancolía, dice, "en triste prosa, mientras un tanto, mi Thalía (su inspiración lírica y pastoril) reposa". N o hay duda de que el ejercicio literario como lenitivo para mitigar las penas, el rechazo o la tristeza, tuvo un poderoso influjo sobre el ánimo creativo de Tresguerras; cosa que, no obstante, poco se entrevera en los temas o las figuras que aborda 0 en la generalidad de sus poemas. Pero al momento en que este hombre autodidacta se retrata con el pómulo detenido contra la palma, apoyado el codo sobre sus libros, abandonado al sueño en su mesa de trabajo y con los pies cruzados (para subrayar que no sólo ha renunciado a sus potencias sino a la facultad de la locomoción), asume conscientemente la imagen de la melancolía "generosa”, como condición ideal del artista que ya participa de una nueva sensibilidad (quizá todavía innombrable entre los suyos). Leamos, con detenimiento, el soneto que pone al calce de la escena, a modo de un a propósito que abre la representación de una comedia:

6I. José C adalso, N oches lúgubres (edición e introducción de Edith H elman), M adrid, T aurus, 1968, pp. 9-65. 


\section{Presenta en sueños, nuestra fantasía objetos, lo más raros y distantes; mas sucesos que vemos en el día los repite entre sombras inconstantes. Así yo: pues soñaba en contra mía, turba de maledicentes y chiflantes. Estos títeres pinto en triste prosa, mientras un tanto, mi Thalía reposa.}

Al advertir que mediante el acto de "embutir el codo entre los montados muebles y con la mano [puesta] en la mejilla", según sus palabras, convocaba a su mente un tropel de "pensamientos melancólicos", el autor no sólo se declaraba vencido por el sueño sino abandonado de la inspiración de su musa predilecta: Thalía, quien preside enmascarada la Comedia, pero cuya ausencia le abre paso a una confesión de tristeza, que le embarga por una momentánea derrota, y que es, al fin y al cabo, el estado ideal, el más anhelado para la gestación de la crítica: la aparición de su "M elpómene desengañada". En esto residía, precisamente, el carácter "positivo" de la M elancholía artificialis de la que habla Panofsky, entendida no tanto como una actitud de afectación extremada del poeta snob (el refugio en la inacción y la noche como disposición para el estudio) sino como el hecho inexorable a que se enfrenta el artista moderno, luego de dar cuerpo a toda invención mental; es decir, cuando se halla cierto de concebir objetos que al fin y al cabo serán vanos y trágicos artificios. Pero más aún: cuando admite la posibilidad de reconocerse en calidad de un sujeto inédito y distinto y que, desde la crisis de la llustración, se encuentra teñido de soledad y escepticismo. \$ 
Bibliografía

Acosta Enríquez, José M ariano, Sueño de sueños (prólogo y selección de Julio Jiménez Rueda), M éxico, Universidad $\mathrm{N}$ acional Autónoma de M éxico (Biblioteca del Estudiante Universitario, núm. 55), 1945.

Alcalá Flecha, Roberto, Literatura e ideología en el arte de G oya, Zaragoza, D iputación G eneral de Aragón, 1988.

Alciato, Andrea, Emblemas (edición y comentario de Santiago Sebastián), M adrid, Akal, 1985. Anónimo, Acuerdos curiosos, Q uerétaro, G obierno del Estado de Q uerétaro, 1989, tomo IV.

Arce, Rubén, La poeśa del siglo ilustrado, M adrid, Alhambra, 198I.

Avilés, M iguel, Sueños ficticios y lucha ideológica en el Siglo de O ro, M adrid, N acional, 198r.

Bozal, Valeriano, G oya y el gusto moderno, M adrid, Alianza Forma, 1994.

Cadalso, José, Noches lúgubres (edición e introducción de Edith H elman), M adrid, Taurus, 1968.

Cuadriello, Jaime, "Un epígono de la tradición: los emblemas en los manuscritos de Francisco Eduardo Tresguerras", en Filippo Picinelli y las dimensiones del arte emblemático (actas del coloquio), El Colegio de M ichoacán, Zamora, M ich. (en prensa).

Gómez Trueba, T eresa, El sueño literario en España, consolidación y desarrollo del género, M adrid, Cátedra, I999.

Goya y el espíritu de la llustración (catálogo de exposición), M adrid-N ueva York, M useo del Prado-M etropolitan M useum of Art, 1988.

Goya, Francisco de, Los caprichos de G oya (introducción y catálogo crítico de Enrique L afuente Ferrari), Barcelona, Gustavo Gilli, 1978.

H elman, Edith, T rasmundo de G oya, M adrid, Alianza Forma, 1983.

J ackson, Stanley W., H istoria de la melancolía y la depresión, M adrid, T urner, 1989.

Klibansky, Raymond, Erwin Panofsky y Fritz Saxl, Saturno y la melancolía, M adrid, Alianza Forma, 1991.

Levitine, G eorge, "Literary Sources of G oya, Capricho 43", en Art Bulletin, vol. XxxvII, 1955.

----, "Some Emblematic Sources of Goya", en Journal of the Warburg and Courtauld Institutes, núms. I-2, vol. XXII, I959.

M artín Gaite, Carmen, U sos amorosos en el di eciocho en España, Barcelona, Anagrama, 1987.

$M$ aza, Francisco de la, "O tra vez T resguerras", en A nales de Instituto de Investigaciones Estéticas, núm. 32, M éxico, U niversidad N acional Autónoma de M éxico, 1963, pp. 53-58.

$\mathrm{M}$ onterde, Francisco, Cultura mexicana ("N avarrete en el prerromanticismo"), M éxico, Intercontinental, 1946, pp. 9I-II8.

$\mathrm{N}$ avarrete, fr. M anuel de, Entretenimientos poéticos (prólogo de Porfirio M artínez Peñalosa), M éxico, Porrúa (Colección de Escritores M exicanos, núms. 93 y 94), I991.

----, Poeśas profanas (prólogo y selección de Francisco M onterde) M éxico, U niversidad N acional Autónoma de M éxico, (Biblioteca del Estudiante U niversitario, núm. 7), 1939. N ordström, Folke, Goya, Saturno y melancolía. Consideraciones sobre el arte de Goya, M adrid, Visor, 1989 . 
O choa y Acuña, Anastasio de, Poeśas de un mexicano (selección y prólogo de M auricio M olina), M éxico, Estanquillo Literario-Instituto $\mathrm{N}$ acional de Bellas Artes, 1987.

0 vidio, Las metamorfosis, M éxico, Porrúa, 1977.

Q uevedo, Francisco de, Los sueños (introducción y notas de J. A. Álvarez Vázquez), M adrid, Alianza, 1983.

---- , Sueños (edición de M ercedes Etreros M ena), M adrid, Plaza \& Janés Clásicos, 1984.

Ripa, Cesare, I conología, M adrid, Akal, 1987.

Rodríguez, Antonio, Colección general de los trages que en la actualidad se usan en España, principiada en el año 1801 en M adrid (edición de Valeriano Bozal), M adrid, Biblioteca de Estampas V isor, 1982.

Sebastián, Santiago, "T heatro moral de la vida humana, de 0 tto V aenius. Lectura y significado de los emblemas", en Boletín del M useo e Instituto Camón Aznar, Zaragoza, vol. XIV, I983.

Tomlinson, J anis A., Francisco de G oya, los cartones para tapices y los comienzos de su carrera en la corte de M adrid, M adrid, Cátedra, 1993.

Toussaint, $M$ anuel, "N uevos aspectos de la biografía de fray $M$ anuel de $N$ avarrete", en Revista M exicana de Literatura o en M anuel Toussaint. O bra literaria (prólogo, bibliografía, recopilación y notas de Luis $\mathrm{M}$ ario Schneider), M éxico, Universidad $\mathrm{N}$ acional Autónoma de M éxico, Instituto de Investigaciones Estéticas, Instituto de Investigaciones Bibliográficas 1992, pp. 513-519.

Tresguerras, Francisco Eduardo, 0 cios literarios (estudio introductorio y notas de Francisco de la M aza), M éxico, U niversidad N acional Autónoma de M éxico, Instituto de Investigaciones Estéticas 1962.

----, 0 cios literarios de don Francisco Eduardo Tresguerras (segunda parte, I80I-I833), manuscrito inédito, colección del $\mathrm{M}$ useo $\mathrm{N}$ acional de ArteI Instituto $\mathrm{N}$ acional de Bellas Artes.

Villarroel, Diego de Torres, Visiones y visitas de Torres con don Francisco de Quevedo por la Corte (edición, introducción y notas de R ussell P. Sebold), M adrid, Espasa-Calpe, 1976.

Wind, Edgar, "Amor sacro y amor profano" y "Amor como D ios de la M uerte", en Los miste rios paganos del Renacimiento, M adrid, Alianza Forma, 1998, pp. I4I-166. 